Really, Mr. Editor, philosophers are rapidly passing into their dotage, and it is high time for those who still retain a mens sana in corpore sano, to combine in the defence of the citadel of truth against their insane and desperate assaults.

I beg to subseribe myself, in much haste, yours obliged and obediently,

Reading, Nov. 1851.

Cinarles Cowan, M.D.

\section{DR. HOLLAND AND THE HOMCEOPATHIC QUACKS.} To the Editor of THe LanceT.

SIR,-I should be little deserving of the confidence placed in me by the Provincial Medical and Surgical Association, as one of the framers of the resolutions passed at the late Brighton meeting, if $I$ withheld from the knowledge of the medical public any instance of the infringement of those rules of professional pro. priety which those resolutions professed to condemn. Accordingly, at the request of the hospital staff of this city, but not without pain, I am compelled to inform you, and through you, your readers in general, that Dr. Holland, Fellow of the Royal College of Physicians, has, within this few days, virtually, if not actually, met in consultation the identical homœopath Bell, whose name has before been noticed in connexion with a most lamentable obstetric case of recent occurrence in Norwich.

That a physician of Dr. Holland's high standing should have so little regard to his own fair fame and name, and to the feelings of the profession to which he belongs, as to eousort with the abettors of homoopathic quackery, is, primâ facie. so incredible, that it is necessary to state that I do not write upon hearsay, but upon the most unexceptionable evidence, to the effect that he not only saw and prescribed for the patient in the presence of the homcopath, but left his treatment to be carried out by that person; and that, after he was made fully aware of his character and mode of practice. The consequence is what might have been predictedthat Dr. Holland is reported to have quite approved of Dr. Bell's treatment (which was homœopathic), and to have agreed with bim in all respects.

Lest it may be thought that $I$ have any interest to serve in this communication, except that of the profession at large, I beg to state, that I am not acquainted with Dr. Holland, Dr. Bell, or the patient. I write at the request of $m y$ colleagues, and in the discharge of my duty as an uncompromising enemy of quackery, and in accordance with a line of conduct to which I feel myself pledged, as one of an influential committee for the suppression of irregular practice.

I am, Sir, your obedient servant,

W. H. Ranking, M.D. (Cantab.)

Norwich, Nov. 1851. Physician to the Norfolk and Norwich Hospital

THE LATE PROTEST AT ST. ANDREW'S. To the Editor of THE LANCET.

Sir,-In The Lancet, (Nov. 1st.) there is a letter from one of our newly-fledged M.D.'s, pretending to correct an error in his address as "London," whereas he wishes the world at large, and his own small sphere in particular, to know that he resides and practises at Emsworth. It is difficult to imagine what motive he had when, with his own hand, he wrote his place of residence as "London,"--whether the paltry cockney idea that he might strike with more self-importance the Board of Examiners collected at St. Andrew's on the occasion; or from an inward conviction that there was a risk of failure, which would pass unnoticed where he was quite unknown, and not transpire in his own little field of practice; but if he succeeded, then this miserable dodge would enable him to be as extensively advertised as the circulation of THE LANCET, and, without even incurring the expense of printing or advertisement duty, let the vicinity of his residence be informed that $\mathrm{Dr}$. Miller now resides, and may be consulted daily, at Emsworth, Hants. The whole tenour of his letter is of the lowest style of virulent abuse, with a pedantic parade of scraps of Latin, possibly picked up from some phrase. book used when grinding up sufficient Latin for his examination in Celsus, to enable him to pass muster among the candidates in Latin-a part of the examination very gently dealt with when the candidate applies from country practice. In order to secure your favour he slyly applands your approval of the "A Almirable Protest," which is somewhat altered from the insolent document which the University refused to receive, and which had to be withdrawn before the ceremony of capping was proceeded with. The statement of what passed is given with a garbled colouring, and one would blush for such conduct, in addition to the artful dodge of the false address, in any one receiving the summi honores of the medical profession. His own insignifieance may save him from further notice, which his rash folly might have exposed him to: but I will consider what steps it may be necessary to adopt if you persist in your virulent personality against me.

When I congratulated Dr. Uwins as "the only gentleman who had shown common sense on the occasion, trusting that his confreres would always hold humbug, and especially anti-homcopathic humbug, in abhorrence"-I was perfectly indifferent what his opinion on homceopathy or mesmerism might be, and feel obliged to Dr. Miller for recording so sensible a reason for Dr. Uwins' declining to subscribe such an unfair and impertinent document.

The paltry attempt to sneer at "the describer of the anatomy of Lucifer and Michael," for treating of a subject of high philosophical anatomy, evidently beyond the intellectual grasp of the petty dodger appearing under false address, I feel to be perfectly contemptible.

As to your fear for the annoyance which the Marquis of Ailsa may have on my account, I believe there is little likelihood of his seeing your tirade, and if he did, he might fancy that a journal was at its shift if it required such a mode of catering for matter to fill up its columns-at the same time it is not likely that he would listen to such an illegal act, even if the whole staff of general practitioners and apothecaries who have graduated here, were to apply for my removal from the University, or from the chair of which he is patron. As you profess "audi alteram partem," I request you will publish this in your next number.

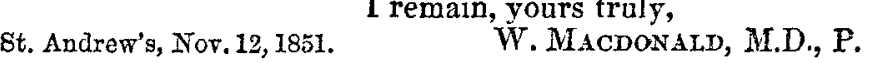

\section{Alevical 担ews.}

Royal College of Surgeons.-The following gentlemen, having undergone the necessary examinations for the diploma, were admitted Members of the College, at the meeting of the Court of Examiners, on the 14th inst.:-

Chibneld, Charles, Tothill-street, Westminster.

Collie, Jazes, A berdeen.

Day, William Edward, Bristol.

Fastwood, Joseph Wrlutam, Chesterfield, Derbyshire.

Prance, Edward Ross, East Stonehouse, Devon.

Roone, James Martin, Fermoy, county of Cork.

Tuxford, James Edward, Boston, Lincolnshire.

At the same meeting of the Court, Mr. JAMES WiLkINSON ElLIOT' passed his examination for naval surgeon. This gentleman had previously been admitted a member of the college, his diploma bearing date November $19,1847$.

Apothecartes' Hall.-Names of gentlemen who passed their examination in the science and practice of modicine, and received certificates to practise, on

Thursday, Nov. 13th, 1851.

Cregeen, James Joseph, Ramsey, Isle of Man.

Wrukxrsor, RoBert, Bradford, Yorkshire.

Medicar Benevolent College. - At a meeting of medical men held at Kentish-town, on the 11th inst., it was resolved,-

"That every effort ought to be made by the profession to support Mr. Propert in his noble undertaking of establishing a Medical Benevolent College.

"That a committee of medical men be at once formed to aid him in that good work.-And

"That the best thanks of the meeting be given to Mr. Propert for his generous efforts for the good of the profession."

The following donations and subscriptions were enter into-

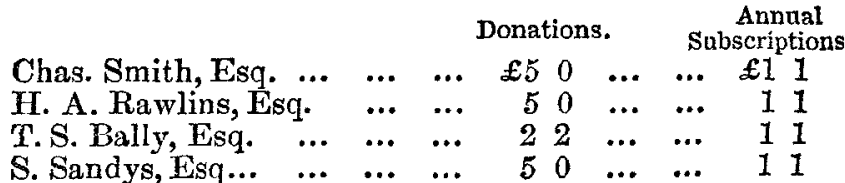

Appointment.-Sir James Eyre has been elected Consulting-Physician to the St. George's and St. James's Dispensary; and has accepted the office at the request of the committee.

Mr. W. Lambton, Surgeon, of Queen's Buildings, Brompton, will read the play of Othello at the St. James's Theatre, on Saturday (this day) night. The profits will be handed orer to the Medical Benevolent College. 